\title{
AMMA's contribution to the evolution of prediction and decision-making systems for West Africa
}

\author{
Jan Polcher, ${ }^{1}$ * Douglas J. Parker, ${ }^{2}$ Amadou Gaye, ${ }^{3}$ Arona Diedhiou, ${ }^{4}$ Laurence Eymard, ${ }^{5}$ Federico Fierli, ${ }^{6}$ \\ Lorenzo Genesio, ${ }^{7}$ Hartmut Höller, ${ }^{8}$ Serge Janicot, ${ }^{5}$ Jean-Philippe Lafore, ${ }^{9}$ Harouna Karambiri, ${ }^{10}$ Thierry Lebel, ${ }^{4}$ \\ Jean-Luc Redelsperger, ${ }^{9}$ Claire E. Reeves, ${ }^{1 /}$ Paolo Ruti, ${ }^{12}$ Inge Sandholt ${ }^{13}$ and Chris Thorncroft ${ }^{14}$ \\ 'LMD/IPSL/CNRS, Paris, France \\ ${ }^{2}$ School of Earth and Environment, University of Leeds, Leeds, UK \\ ${ }^{3}$ LPAO-SF/UCAD, Dakar, Senegal \\ ${ }^{4}$ LTHE/IRD, Grenoble, France \\ ${ }^{5}$ LOCEAN/IPSL/CNRS, Paris, France \\ 6ISAC/CNR, Bologna, Italy \\ ${ }^{7}$ IBIMET/CNR, Florence, Italy \\ ${ }^{8}$ Deutsches Zentrum für Luft- und Raumfahrt, Institut für Physik der Atmosphäre, Oberpfaffenhofen, Germany \\ ${ }^{9}$ CNRM-GAME, Météo-France and CNRS, Toulouse, France \\ ${ }^{10}$ 2iE, Ouagadougou, Burkina Faso \\ IISchool of Environmental Sciences, UEA, Norwich, UK \\ 12 ENEA, Rome, Italy \\ ${ }^{13}$ Department of Geography, University of Copenhagen, Copenhagen, Denmark \\ ${ }^{14}$ Department of Earth and Atmospheric Sciences, University at Albany, SUNY, Albany, NY, USA
}

*Correspondence to: Jan Polcher, CNRS, LMD/IPSL, Tour 45, Case 99, 4 Place Jussieu, Paris 75252, France. E-mail: jan.polcher@lmd.jussieu.fr

Received: 24 February 2010

Revised: 2 December 2010

Accepted: 5 December 2010

\begin{abstract}
The AMMA (African Monsoon Multidisciplinary Analysis) project set out to better understand the geophysical processes which govern the evolution of the monsoon and provide the science needed to improve prediction and decision-support systems. The control exerted by weather and climate on agronomic production, water resources and public health was studied to evaluate the potential for populations to adapt. AMMA made advances which have the potential to improve forecasts from weather to climate scales. Translating them into operational tools for decision making will require improvements to the observational networks, and stronger support for the organizations which generate and disseminate application forecasts. Copyright $(2011$ Royal Meteorological Society
\end{abstract}

Keywords: review; forecasting; monitoring; health; water resources; agriculture; overview; climate

\section{Introduction}

West Africa's climate is characterized by a monsoonal system which brings precipitation to the region from May to September. The brevity of the rainfall period imposes strong constraints on rainfed agriculture, which remains the dominant economic sector in the region and the main component of food security for local population.

Furthermore, the large intra-seasonal and interannual variability of rainfall imposes the use of resilient agronomic techniques. These limits on the availability of water also impact on other aspects of the socio-economic structures such as public health, water resources for urban areas and energy production. This region is a hot-spot for the interaction between climate and the socio-economic systems, which is particularly vulnerable to climate variability and climate change (Pachauri and Reisinger, 2007).

The African Monsoon Multidisciplinary Analysis (AMMA) set out to improve our understanding of the processes governing the West African Monsoon
(WAM) and advance our knowledge of how its annual evolution and inter-annual variability affect food security, water resources and public health in the region (Redelsperger et al., 2006). Because of the strong links in this region between climate and the socioeconomic system, the research was multidisciplinary and aimed at demonstrating possible improvements to current prediction and early warning systems (EWS). AMMA needed also to bring together the African and International research communities in order to ensure a long-term benefit of the new knowledge for societies in the region. For these objectives AMMA obtained the support of World Climate Research program (WCRP) and International Geosphere-Biosphere Programme (IGBP).

Since the droughts and famines of the 1970s and 1980s, efforts were undertaken by national and regional agencies to integrate meteorological information in EWS, in order to provide appropriate and timely information to support decision making for food crisis prevention and management. Currently the early warning process is based on an information network 
operating at national level and involving extension services and international organizations. A key role in the process is played by National Weather Services (NWS) that coordinate and integrate multidisciplinary information, providing early information on crop-risk areas to decision makers, ensuring the monitoring of the agricultural season and, in some countries, disseminating information to farmers to orient agricultural strategies.

At regional level, in order to provide pre-alerts for regional scale food crises, the PRESAO forum (PREvision Saisonnière en Afrique de l'Ouest), coordinated by the African Centre of Meteorological Applications for Development (ACMAD), elaborates each year in May consensual probabilistic forecasts of rainfall amounts from July to September based on forecasts made by centres around the world. Also at regional level the AGRHYMET Regional Centre provides bulletins on the monitoring of the agricultural campaign.

This paper will show how studies in AMMA helped improve the meteorological and agronomic information that support the early warning process. We also show how crop yield forecasts and other information provided to decision makers can be made more pertinent. We describe some of the key successes of AMMA and make recommendations for the future.

\section{Improved environmental observations and observing networks}

A first step towards improving the information for EWS is to have in place appropriate observing networks. These provide initial conditions for forecasts, data for verification and, over the long term, a database which can serve as a basis for hindcasts, trend analysis and statistical downscaling. With the objectives of demonstrating the value of an improved observing network and to support the intensive geophysical research, AMMA deployed an unprecedented network of observing systems in the region, particularly during the Extended Observing Period from 2005 to 2007 (Lebel et al., 2011).

A major achievement of the project was to upgrade the upper-air radio sounding network (Parker et al., 2008). For most of the francophone countries of the region the network is operated by ASECNA, while in Ghana and Nigeria the NWS have this responsibility. All three institutions worked closely together in order to increase the density of the network, adapt the stations to the newest technology and ensure a reliable transfer of observations on the Global Telecommunication System. AMMA has demonstrated that given the funding, agencies in the region can operate the upper-air network to the same standards as other parts of the world and that the extra data positively impacts forecasts over the region as well as outside of this domain and especially over Europe (Agusti-Panareda et al., 2010a).

AMMA has used and expanded the environmental observatories in the region. Central were those for hydrology and surface processes in the upperOuémé, Niamey region and the Gourma (Lebel et al., 2009). Regional networks for aerosols and air pollution were reinforced (Marticorena et al., 2011). For socio-economic studies, observatories for agricultural practices and adaptation to climate vulnerabilities were centrally established (Mertz et al., 2011; Traoré et al., 2011). These monitoring activities have contributed to a better understanding of the processes and allowed us to evaluate the models used for forecasting water resources or crop yields, for instance. Nevertheless, their true value will emerge over time when the records will be sufficiently long to analyse trends and understand their origins and consequences. The best example here is the work over the Niamey basin which was started in the early 1990s and now allows us to understand the interplay between rainfall fluctuations, land use and water resources (Cappelaere et al., 2009). Very few of these observatories in the region are supported at the national or regional level. This is a major concern as they will be central to establishing climate services and only a strong support from national or regional agencies will ensure their longterm continuation.

The exchange of observations remains a serious challenge in the region. The real-time transmission of data to international meteorological centres, for instance, is hampered by the lack of robust and resilient telecommunication networks. Often the networks dedicated to this type of exchange are outdated and do not have back-up systems. The telecommunication tools for the general public (Internet or GSM) are more reliable but only reluctantly used by international operational services (Parker et al., 2008). The exchange of observations between operational services in the region and with the research community is very difficult, in part due to restrictive national policies and a lack of trust between the operational services and the research community. This state of affairs limits the exploitation of observations, the development of knowledge and forecasting tools by the West African research community, and the development of research capacity. In an attempt to undo this deadlock, AMMA established an open data policy for research activities and entrusted AGRHYMET with the regional mirror of the AMMA database (Fleury et al., 2011).

\section{Improved knowledge and understanding of processes}

The AMMA observational programme, ranging from the long-term observations to the intensive field campaigns, has led to increased knowledge of geophysical and environmental processes in the region. Processoriented models are key in building prediction and decision-support systems because they allow us to put observations into context and they can retain their predictive capabilities in an evolving environment. Our understanding of the physical, chemical and aerosol 
processes in the atmosphere has greatly progressed during the AMMA project (Lafore et al., 2011; Mari et al., 2011; Marticorena et al., 2011) and important deficiencies in models have been identified (Ruti et al., 2011). The 3-4 years since the AMMA intensive field campaign has been too short to translate the new knowledge into new parametrizations and improved operational models, but the long-term potential is very strong.

For instance, one major achievement of the project was to identify feedbacks between mesoscale soil moisture structures left by the passage of a convective systems and the development of subsequent storms (Taylor et al., 2011). This surface/atmosphere interaction brings some potential predictability, but introducing observed mesoscale soil moisture structures in the European Centre for Medium-Range Weather Forecasts (ECMWF) model forecast system has not yet produced the expected improvements (AgustiPanareda et al., 2010b). This is a clear indication that model deficiencies in the tropics remain a challenge and that AMMA observations will be used for years to come for model development, as outlined in the International Science Plan of the second AMMA phase.

A comparable situation prevails in land surface modelling. The AMMA Land surface Model Intercomparison Project (ALMIP) allowed us to identify large divergences of models in the infiltration and runoff they simulate (Boone et al., 2009) and thereby provided limits on the confidence we can place in predictions of the impact of rainfall fluctuations and land use on water resources. The new knowledge gained on hydrological processes in the Guinean and Sahelian zones has lead to improved process models (Séguis et al., 2011). This allowed us to reproduce and understand the impact of past rainfall fluctuations and land use evolution on aquifer levels (Boulain et al., 2009). It will take a few more years until the new knowledge gained in AMMA is translated into advances for land surface models enabling them to predict with sufficient confidence droughts and water resources at the regional scale.

For the ocean, the error in reproducing the summer cold/warm events in the eastern equatorial Atlantic is another critical factor which limits the forecasting skill over West Africa. The processes determining the Atlantic cold tongue variability have been analysed within the AMMA framework (Brandt et al., 2011), and now a specific effort is needed to improve the coupled models used for climate projections and seasonal forecasts.

The on-farm observations and experimental trials performed within the agronomic observatories have allowed us to gather the data needed to validate and improve the agronomic models (Traoré et al., 2011). Similar progress has been obtained for the rift valley fever and malaria risk models (Caminade et al., 2011). In a first attempt to apply these models at the regional scale they have been driven by the output of regional climate models for present and future climates (Paeth et al., 2011). These prospective studies have demonstrated the potential of these models but more work is needed to establish their skill and integrate them in seasonal EWS driven by ensembles of seasonal deterministic forecasts (Hagedorn et al., 2005).

\section{A multidisciplinary approach for advancing prediction and EWS}

Research can demonstrate forecast potential but the quality of actual forecasts and their acceptance by users will depend on the technical effort of combining the right observations and models, and deriving the diagnostics which are useful to the decision maker. The survey of farmers conducted by AMMA clearly indicates that rainfall fluctuations (quantity and seasonal distribution) are perceived as a threat by farmers. On the other hand, long-term climate trends impose weak constraints on livelihoods compared to other socio-economic evolutions (Mertz et al., 2011). This highlights the need to focus our attention on prediction systems for timescales from synoptic to seasonal in order to inform agricultural activities and to allow farmers to plan ahead. Climate advice on longer time scales will mostly be needed for the development and adaptation of large-scale infrastructures.

Studies of the inter-annual and intra-seasonal fluctuations of rainfall have highlighted a range of mechanisms and related structures as well as teleconnection patterns which suggest a potential for predictability (Janicot et al., 2011; Rodriguez et al., 2011). The challenge today is to better realize this potential. Statistical forecasts or the consensus process of the PRESAO are not as skilful as needed and the predicted seasonal mean rainfall is not the most pertinent information for decision makers (Bouali, 2009). Although dynamical models have large biases in their seasonal forecasts, AMMA has demonstrated that appropriate model output statistics could turn them into skilful tools (Philippon et al., 2010). Despite this difficulty and the time scales for improving coupled models, ensembles of dynamical forecasts offer a number of advantages. They allow more relevant diagnostics of the predicted rainy season, such as for instance the timing of the onset and end of the season, or the probability of long breaks. Furthermore, as the same model can be used from the synoptic to the seasonal scale it provides a seamless suite of forecasts which can be updated throughout the season. This is an essential element for the progress of EWS for food security (Genesio et al., 2011).

AMMA generated in 2008 and 2009 risk maps for cereal production based on seasonal dynamical forecasts and assessed their relevance for decision making. In the same way, seasonal hindcasts have been used to simulate malaria probability risk maps. These products still show strong deficiencies and are far from ready for operational implementation. 
Nevertheless they demonstrate the potential of these tools and allow us to discuss the steps needed to produce valuable products for decision makers. It is clear today that global dynamical forecasting systems will not be implemented in Africa in the near future, while organizations such as ECMWF, Météo-France, the Met Office and National Centers for Environmental Prediction (NCEP) are making their ensemble seasonal forecasts available to the African agencies. On the other hand, it is essential that the crop yield, water resource or public health models which produce the diagnostics to be used in decision-making systems are run by national and regional agencies. First, this local control of application models ensures that a critical regional analysis of the seasonal forecasts is performed before their usage. Second, in the application models climate/weather is only one of many drivers, and a constant monitoring and validation, with data from observatories, is needed, and a diversity of tools advisable. Third, decision makers use information from application models with an appreciation of their origin and therefore, the credentials of the national or regional agencies are essential.

It is our recommendation after 7 years of AMMA that in order to build these chains of decision-support systems, West African weather services need to be strengthened. Today, they already play the role of connecting weather and climate forecasts with application models for decision making, but they require the personnel which can transform research results such as those presented above into operational tools. The agronomic agencies in the region are more involved in the research and are active developers of application models, but their connection to operational activities needs to be developed. This situation is bound up with the relatively weak university programmes in environmental sciences, and an under-critical research community which cannot train sufficient students to the $\mathrm{PhD}$ level (Danuor et al., 2011). Expanding the research and technical communities in universities and environmental agencies is certainly the best prospect for building decision-support systems in the region, and by the same token improving the ability of the West African societies to cope with climate variability and changes.

\section{Conclusion}

AMMA, as a research project, has brought new knowledge regarding processes governing the monsoon and its variability, and on the processes which link the climate system and human activities.

The project has shown that prediction and decisionsupport systems which provide better and more relevant information to stakeholders are possible today. This advancement of our knowledge has allowed the community to identify new gaps in our understanding, missing observations in the networks and components of our models which need improving. Further research on tropical climates and particularly Africa is needed: the second phase of AMMA, as well as other funded research projects, will contribute to this.

AMMA has also shown that environmental research, observations and forecasting in West Africa do not get the attention needed. In view of the large variability of the African climate at all scales, and the high vulnerability of the populations, strong and effective environmental decision-support systems are needed. To produce these climate services, West Africa needs denser observing networks and long-term monitoring of the environment. The exchange of data and knowledge between operational services and the African research community needs to be intensified. A specific effort is required to strengthen the agencies in the region, to ensure that new results from research are quickly transferred into operations. This has to be done with a close involvement of decision makers, so that valuable products are provided to the users. In order to have the human resources needed to enhance environmental services, university programmes and the research community have to be strengthened, and a dedicated effort is required to widen the availability of masters' programmes and doctoral schools. Such an investment in research and educational programmes for environmental sciences and their application in West Africa will greatly increase the adaptation potential of the socio-economic structures of the region.

\section{Acknowledgements}

The support of the AMMA project is gratefully acknowledged (see http://onlinelibrary.wiley.com/doi/10.1002/asl.331/full for full acknowledgement).

\section{References}

Agusti-Panareda A, Beljaars A, Ahlgrimm M, Balsamo G, Bock O, Forbes R, Ghelli A, Guichard F, Köhler M, Meynadier R, Morcrette J-J. 2010a. The ECMWF re-analysis for the AMMA observational campaign. Quarterly Journal of the Royal Meteorological Society 136: 1457-1472.

Agusti-Panareda A, Balsamo G, Beljaars A. 2010b. Impact of improved soil moisture on the ECMWF precipitation forecast in the AMMA region. Geophysical Research Letters submitted.

Bouali L. 2009. Prévisibilité et prévision statistico-dynamique des saisons des pluies associées à la mousson oust africaine à partir d'ensembles multi-modèles. Thèse de doctorat. Université de Bourgogne, Dijon; 158.

Boulain N, Cappelaere B, Séguis L, Favreau G, Gignoux J. 2009. Water balance and vegetation change in the Sahel: a case study at the watershed scale with an eco-hydrological model. Journal of Hydrology 375: 190-203.

Boone A, de Rosnay P, Balsamo G, Beljaars A, Chopin F, Decharme B, Delire C, Ducharne A, Gascoin S, Guichard F, Gusev Y, Harris P, Jarlan L, Kergoat L, Mougin E, Nasonova O, Norgaard A, Orgeval T, Ottlé C, Poccard-Leclercq I, Polcher J, Sandholt I, Saux-Picart S, Taylor C, Xue Y. 2009. The AMMA Land Surface Model Intercomparison Project (ALMIP), Bull. Atmos. Meteor. Soc. 90: 1865-1880.

Brandt P, Caniaux G, Bourlès B, Lazar A, Dengler M, Funk A, Hormann V, Giordani H, Marin F. 2011. Equatorial upper-ocean dynamics and their interaction with the West African monsoon. Atmospheric Science Letters 12: 24-30, DOI: 10.1002/asl.287. 
Caminade C, Ndione JA, Kebe CMF, Jones AE, Danuor S, Tay S, Tourre YM, Lacaux J-P, Duchemin JB, Jeanne I, Morse AP. 2011. Mapping rift valley fever and malaria risk over West Africa using climatic indicators. Atmospheric Science Letters 12: 96-103, DOI: 10.1002/asl.296

Cappelaere B, Descroix L, Lebel T, Boulain N, Ramier D, Laurent JP, Favreau G, Boubkraoui S, Boucher M, Bouzou Moussa I, Chaffard V, Hiernaux P, Issoufou HBA, Le Breton E, Mamadou I, Nazoumou Y, Oi M, Ottle' C, Quantin G. 2009. The AMMACATCH experiment in the cultivated Sahelian area of southwest Niger - Investigating water cycle response to a fluctuating climate and changing environment. Journal of Hydrology 375: 34-52.

Danuor S, Gaye A, Yacouba H, Mariko A, Ibrahim Bouzou M, Maiga M, Da D, Ginoux K, Parker DJ, Polcher J, Laval K, Diallo D. 2011. Education in meteorology and climate sciences in West Africa. Atmospheric Science Letters 12: 155-159, DOI 10.1002/asl.326.

Fleury L. 2011. AMMA information system: an efficient crossdisciplinary tool and a legacy for forthcoming projects. Atmospheric Science Letters 12: 149-154, DOI: 10.1002/asl.303.

Genesio L, Bacci M, Baron C, Diarra B, Di Vecchia A, Alhassane A, Hassane I, Ndiaye M, Philippon N, Tarchiani V, Traoré S. 2011. Early warning systems for food security in West Africa: evolution, achievements and challenges. Atmospheric Science Letters 12 142-148, DOI: 10.1002/asl.332.

Hagedorn R, Doblas-reyes FJ, Palmer TN. 2005. The rationale behind the success of multi-model ensembles in seasonal forecasting. Tellus 57(3): 219-233.

Janicot S, Caniaux G, Chauvin F, de Coëtlogon G, Fontaine B, Hall N, Kiladis G, Lafore J-P, Lavaysse C, Lavender SL, Leroux S, Marteau R, Mounier F, Philippon N, Roehrig R, Sultan B, Taylor CM. 2011. Seasonal and intra-seasonal variability of the West African monsoon. Atmospheric Science Letters 12: 58-66, DOI: 10.1002/asl.280.

Lafore J-P, Flamant C, Guichard F, Parker DJ, Bouniol D, Fink AH, Giraud V, Gosset M, Hall N, Höller H, Jones SC, Protat A, Roca R, Roux F, Saïd F, Thorncroft C. 2011. Progress in understanding of weather systems in West Africa. Atmospheric Science Letters 12: 7-12, DOI: 10.1002/asl.335.

Lebel T, Cappelaere B, Vieux B, Galle S, Hanan N, Kergoat L, Levis S. 2009. Surface processes and water cycle in West Africa, studied from the AMMA-CATCH observing system. Journal of Hydrology 375: 1-3.

Mari C. 2011. Atmospheric composition of West Africa: highlights from the AMMA international program. Atmospheric Science Letters 12: $13-18$, DOI: $10.1002 /$ asl.289.

Marticoréna B, Haywood J, Coe H, Formenti P, Liousse C, Mallet M, Pelon J. 2011. Tropospheric aerosols over West Africa highlights from the AMMA international project. Atmospheric Science Letters 12: 19-23, DOI: $10.1002 /$ asl.322.

Mertz O, Mbow C, Reenberg A, Genesio L, Lambin EF,D'haen S, Zorom M, Rasmussen K, Diallo D, Barbier B, Bouzou Moussa I, Diouf A, Nielsen JØ, Sandholt I. 2011. Adaptation strategies and climate vulnerability in the Sudano-Sahelian region of West Africa. Atmospheric Science Letters 12: 104-108, DOI: 10.1002/asl.314.
Pachauri RK, Reisinger A. 2007. Contribution of Working Groups I, II and III to the Fourth Assessment Report of the Intergovernmental Panel on Climate Change. IPCC: Geneva, Switzerland; 104.

Paeth H, Hall NMJ, Gaertner MA, Dominguez Alonso M, Moumouni S, Polcher J, Ruti PM, Fink AH, Gosset M, Lebel T, Gaye AT, Rowell DP, Moufouma-Okia W, Jacob D, Rockel B, Giorgi F, Rummukainen M. 2011. Progress in regional downscaling of West African precipitation. Atmospheric Science Letters 12: 75-82, DOI: 10.1002/asl.306.

Parker DJ, Fink A, Janicot S, Ngamini J-B, Douglas M, Afiesimama E, Agusti-Panareda A, Beljaars A, Dide F, Diedhiou A, Lebel T, Polcher J, Redelsperger J-L, Thorncroft C, Wilson GA. 2008. The AMMA radiosonde programme and its implications for the future of atmospheric monitoring over Africa. Bulletin of the American Meteorological Society 1015-1027.

Philippon N, Doblas Reyes F, Ruti P. 2010. Skill, reproducibility and potential predictability of the West African monsoon in coupled GCMs. Climate Dynamics 35: 53-74.

Redelsperger JL, Thorncroft C, Diedhiou A, Lebel T, Parker D, Polcher J. 2006. African monsoon multidisciplinary analysis: an international project and field campaign. Bulletin of the American Meteorological Society 87(12): 1739-1746.

Rodríguez-Fonseca B, Janicot S, Mohino E, Losada T, Bader J, Caminade C, Chauvin F, Fontaine B, García-Serrano J, Gervois S, Joly M, Polo I, Ruti P, Roucou P, Voldoire A. 2011. Interannual and decadal SST forced responses of the West African monsoon. Atmospheric Science Letters 12: 67-74, DOI: 10.1002/asl.308.

Ruti PM, Williams JE, Hourdin F, Guichard F, Boone A, Van Velthoven P, Favot F, Musat I, Rummukainen M, Domínguez M, Gaertner A, Lafore JP, Losada T, Rodriguez de Fonseca MB, Polcher J, Giorgi F, Xue Y, Bouarar I, Law K, Josse B, Barret B, Yang X, Mari C, Traore AK. 2011. Modeling the West African climate system: systematic errors and future steps. Atmospheric Science Letters 12: 116-122, DOI: 10.1002/asl.305.

Séguis L, Boulain N, Cappelaere B, Cohard JM, Favreau G, Galle S, Guyot A, Hiernaux P, Mougin E, Peugeot C, Ramier D, Seghieri J, Timouk F, Demarez V, Demarty J, Descroix L, Descloitres M, Grippa M, Guichard F, Kamagaté BS, Kergoat L, Lebel T, Le Dantec V, Le Lay M, Massuel S, Trichon V. 2011. Contrasted land surface processes along the West African rainfall gradient. Atmospheric Science Letters 12: 31-37, DOI: 10.1002/asl.327.

Traoré SB, Alhassane A, Muller B, Kouressy M, Somé L, Sultan B, Oettli P, Siéné Laopé AC, Vintrou E, Sangaré S, Vaksmann M, Diop M, Bégué A, Dingkhun M, Baron C. 2011. Characterizing and modelling the diversity of cropping situations under climatic constraints in West Africa. Atmospheric Science Letters 12: 89-95, DOI: $10.1002 /$ asl.295.

Taylor CM, Parker DJ, Kalthoff N, Gaertner MA, Philippon N, Bastin S, Harris PP, Boone A, Guichard F, Agusti-Panareda A, Baldi M, Cerlini P, Descroix L, Douville H, Flamant C, Grandpeix J-Y, Polcher J. 2011. New perspectives on landatmosphere feedbacks from the African Monsoon Multidisciplinary Analysis. Atmospheric Science Letters 12: 38-44, DOI: 10.1002/asl.336. 